\title{
Bibliography
}

\section{Archival sources}

1.1 Files held at the National Archives, formerly the Public Record Office, Kew, London

CAB 66/7 - 'British Strategy in a Certain Eventuality'. Report by the Chiefs of Staff, 25 May 1940.

CAB 121/305 - 'Organisation and Control of the Special Operations Executive (SOE).

CO 537/1210 - 'Revision of British Nationality and Status of Aliens Act: Married Women', 1946.

HS 6/568 - France: Circuit and mission reports and interrogations: Cammaerts to Cruzel, 1944-1945.

HS 6/569 - France: Circuit and mission reports and interrogations: Dennery to Duquesne, 1944-1945.

HS 6/573 - France: Circuit and mission reports and interrogations: Istria to Knight, 1944-1945.

HS 6/576 - France: Circuit and mission reports and interrogations: Nearne to Noyer, 1944-1945.

HS 7/55 - Histories and War Diaries: Lecture folder STS 103; Part 1, 1943-1944.

HS 7/66 - Histories and War Diaries: SOE Group B training manual regional supplement: France, Netherlands and Norway [c.1940-1945].

HS 7/135 - Histories and War Diaries: Evaluation of SOE activities in France 1941-1944 [c.1941-1944].

HS 8/371 - Ministry of Economic Warfare, Special Operations Executive and Successors: Headquarters: Records: Recruitment and training: Lectures and statistics, 1942 Jan $01-1942$ Dec 31.

HS 8/858 - Ministry of Economic Warfare, Special Operations Executive and 


\section{Bibliography}

Successors: Headquarters: Security: Publications, 1942 Jan 01 - 1948 Dec 31.

HS 9/10/2 - Personal File, Françoise Agazarian [also know as Françine Agazarian].

HS 9/11/1 - Personal File, Jack Agazarian.

HS 9/77/1 - Personal File, Lise de Baissac.

HS 9/114/2 - Personal File, Yolande Beekman

HS 9/165/8 - Personal File, Denise Bloch.

HS 9/183 - Personnel File, Andrée Borrel.

HS 9/250/2 - Personal File, Muriel Byck.

HS 9/258/5 - Personal File, Francis Cammaerts.

HS 9/298/6 - Personal File, Blanche Charlet.

HS 9/314 - Personnel File, Peter Churchill.

HS 9/339/2 - Personal File, Anne-Marie Walters.

HS 9/457/6 - Personal File, Yvonne Fontaine.

HS 9/612 - Personal File, Christine Granville.

HS 9/648/4 - Personal File, Odette Sansom.

HS 9/747/4 - Personal File, Christopher Sydney Hudson.

HS 9/836/5 - Personal File, Noor Inayat Khan.

HS 9/910/3 - Personal File, Vera Leigh.

HS 9/1240/3 - Personal File, Harry Rée.

HS 9/1419/8 - Personal File, Brian Stonehouse.

HS 9/1435 - Personal File, Violette Szabo.

LO 3/604 - British Nationality and Status of Aliens Act, 1914.

\subsection{SOE box held at FANY HQ}

Memo - 'Some examples of discrepancies in civil/military awards', 22 October 1945.

\section{Oral History}

2.1 Conducted by author

\begin{tabular}{lll}
\hline $\begin{array}{l}\text { Date of } \\
\text { interview }\end{array}$ & Interviewee & Wartime occupation \\
\hline $01 / 04 / 99$ & M. R. D. Foot & Author of official history of SOE \\
$03 / 06 / 99$ & Gervase Cowell & Ex-SOE Adviser, Foreign Office \\
$02 / 07 / 99$ & Vera Atkins & Intelligence Officer, F Section \\
$23 / 07 / 99$ & May Shrubb (née Shrewsbury) & ATS Tailoress \\
$28 / 07 / 99$ & Francis Cammaerts & SOE agent, F Section. \\
$18 / 08 / 99$ & Nancy Wake-Forward (née Wake) & SOE agent, F Section \\
$25 / 08 / 99$ & Roger Landes & SOE agent, F Section \\
$27 / 08 / 99$ & Derrick Duesbury & Security Section \\
$28 / 08 / 99$ & Yvonne Burney (née Baseden) (1) & SOE agent, F Section \\
$22 / 09 / 99$ & Eric Sheppard & Instructor \\
$24 / 10 / 99$ & Maisie McLintock (née Sim) & SOE-FANY Coder
\end{tabular}




\section{Bibliography}

$\begin{array}{lll}21 / 11 / 99 & \text { Dorothy Wakely (née Temple) } & \text { SOE-FANY Signal Planner } \\ 11 / 04 / 00 & \text { Yvonne Burney (née Baseden) (2) } & \text { SOE agent, F Section } \\ 11 / 08 / 00 & \text { Cyril Watney } & \text { SOE agent, F Section } \\ 17 / 04 / 02 & \text { Lise Villameur (née de Baissac) } & \text { SOE agent, F Section } \\ 08 / 06 / 02 & \text { Sydney Hudson } & \text { SOE agent, F Section } \\ 20 / 06 / 02 & \text { Pru Hannay (née Willoughby) } & \text { Security Section } \\ 19 / 06 / 02 & \text { Claire Everett (pseudonym) } & \text { SOE agent, F Section } \\ 30 / 07 / 02 & \text { Bob Sheppard } & \text { SOE agent, F Section } \\ 31 / 07 / 02 & \text { Gaston Collins (né Cohen) } & \text { SOE agent, F Section } \\ 31 / 07 / 02 & \text { Bob Maloubier } & \text { SOE agent, F Section }\end{array}$

2.2 Transcripts of media interviews

\begin{tabular}{llll}
\hline Name of interviewee & Programme & Channel & Year \\
\hline Sonya Butt & $\begin{array}{l}\text { Behind Enemy Lines: The Real } \\
\text { Charlotte Grays }\end{array}$ & Channel 4 & 2002 \\
& Churchill's Secret Army & Channel 4 & 2000 \\
Ralph Beauclerk & Secret Agent & BBC2 & 2000 \\
Yvonne Burney (Baseden) & Churchill's Secret Army & Channel 4 & 2000 \\
Francis Cammaerts & Secret Agent & BBC2 & 2000 \\
Francis Cammaerts & Behind Enemy Lines: The Real & Channel 4 & 2002 \\
Francis Cammaerts & Charlotte Grays & & \\
& Secret Agent & BBC2 & 2000 \\
Henri Diacono & Churchill's Secret Army & Channel 4 & 2000 \\
Peter Lake & Secret Agent & BBC2 & 2000 \\
Roger Landes & Churchill's Secret Army & Channel 4 & 2000 \\
Jacques Poirier & Secret Agent & BBC2 & 2000 \\
Claudia Pulver & Behind Enemy Lines: The Real & Channel 4 & 2002 \\
Lise Villameur (de & Charlotte Grays & & \\
Baissac) & Churchill's Secret Army & Channel 4 & 2000 \\
André Watt & Secret Agent & BBC2 & 2000 \\
Guido Zembsch-Schreve & & & \\
\hline
\end{tabular}

2.3 Taped interviews with ex-SOE members held at the IWM SA

\begin{tabular}{llll}
\hline Name of interviewee & $\begin{array}{l}\text { IWM tape Source } \\
\text { number }\end{array}$ & $\begin{array}{l}\text { Date of } \\
\text { interview }\end{array}$ \\
\hline $\begin{array}{l}\text { Robert Boiteux-Burdett } \\
\text { Tony Brooks }\end{array}$ & 16568 & $\begin{array}{l}\text { IWM SA } \\
\text { 'Reminiscences of a British } \\
\text { Agent' (lecture at IWM) }\end{array}$ & 1988 \\
$\begin{array}{l}\text { Maurice Buckmaster } \\
\text { Maurice Buckmaster }\end{array}$ & 8680 & BBC Radio 4, Set Europe Ablaze & 1983 \\
$\begin{array}{l}\text { Yvonne Cormeau } \\
\text { Yvonne Cormeau }\end{array}$ & 7369 & IWM SA & 1986 \\
$\begin{array}{l}\text { Pearl Cornioley } \\
\text { (Witherington) }\end{array}$ & 8885 & BBC Radio 4, Set Europe Ablaze & 1983 \\
& & BBC Radio 4, Set Europe Ablaze & 1983
\end{tabular}




\section{Bibliography}

\begin{tabular}{llll}
\hline Name of interviewee & $\begin{array}{l}\text { IWM tape } \\
\text { number }\end{array}$ & $\begin{array}{l}\text { Date of } \\
\text { interview }\end{array}$ \\
\hline $\begin{array}{l}\text { Pearl Cornioley } \\
\text { (Witherington) }\end{array}$ & 10447 & IWM SA & 1988 \\
Harry Despaigne & 9925 & IWM SA & 1987 \\
Edgar Hargreaves & 5378 & IWM SA & 1981 \\
Selwyn Jepson & 9331 & IWM SA & 1986 \\
Peter Lee & 7473 & IWM SA & 1984 \\
Kenneth Mackenzie & 18154 & IWM SA & 1996 \\
Jos Mulder-Gemmeke & 12297 & BBC Radio 4, Set Europe Ablaze & 1983 \\
Harry Rée & 8688 & BBC Radio 4, Set Europe Ablaze & 1983 \\
Harry Rée & 8720 & IWM SA & 1995 \\
Odette Hallowes & 9478 & IWM SA & 1986 \\
(Sansom) & & & 1988 \\
Bob Sheppard & 10445 & IWM SA & 1987 \\
Brian Stonehouse & 9852 & IWM SA & 1996 \\
Brian Stonehouse & 18156 & IWM SA &
\end{tabular}

\section{Correspondence}

\subsection{Written correspondence}

Pearl Cornioley (Witherington) - 8 July 1999.

Sydney Hudson - 14 March 2002.

Duncan Stuart - 25 February 1999.

André Watt - 17 January 2003.

Anonymous combatant in Greece - 28 March 2000.

Anonymous combatant in Greece - 14 October 1999.

Anonymous combatant in the Middle East - 3 November 1999.

\subsection{Email}

Shrabani Basu, biographer, 12 October 2006.

\subsection{Telephone conversations}

Yvonne Burney (Baseden) - 6 November 2000.

\section{Newspapers}

Simpson, W., 'WAAF girls parachuted into France', Sunday Times (11 March 1945).

'Girl who was dropped over France missing', News of the World (17 March 1946). 'Story of the woman who knew how to die: Nazi firing squad was moved', News

Chronicle (30 March 1946). 


\section{Bibliography}

'The story behind a tragic picture: women agents' death mystery solved: last hours in concentration camp after parachute leap', newspaper unknown (31 March 1946).

'British women burned alive: German camp staff charged', Daily Telegraph and Morning Post (30 May 1946).

Lane, M., 'The story of four British Secret Service women: parachutists did not return'. Newspaper unknown and undated. Clipping held at FANY HQ.

O'Brien, W., 'G.C. woman withstood red-hot iron torture', Daily Graphic (undated). [August 1946].

'First British Woman GC: Fought gun battle alone with the Gestapo', Daily Graphic (and Daily Sketch) (18 December 1946).

'Girl who was dropped over France missing', News of the World (1946).

'Odette G.C. wed today' (newspaper unknown and undated) [1947].

'Couple who fooled Gestapo marry' (newspaper unknown and undated) [1947].

Review of School for Danger, P. Kirwan, Evening Standard (6 February 1947).

Review of School for Danger, To-day's Cinema, Vol. 68, No. 5457 (7 February 1947).

Review of School for Danger, The Times (7 February 1947).

Review of School for Danger, 'A seat in the stalls', Sunday Express (7 February 1947).

Review of School for Danger, C. C. Lejeune, Observer (9 February 1947).

Review of School for Danger, 'Reviews for Showmen', Kinematograph Weekly, No. 2078 (13 February 1947).

Review of School for Danger, R. Mortimer, The New Statesman and Nation (15 February 1947).

Review of School for Danger, Showmen's Trade Review (22 February 1947).

Review of School for Danger, 'At the Pictures - round up', Punch or the London Charivari (5 March 1947).

Review of School for Danger, F. Majdalany, Daily Mail (undated). Clipping held at the British Film Institute, Item 31.

Review of School for Danger, R. Winnington, News Chronicle (undated). Clipping held at the British Film Institute, Item 31.

Review of School for Danger, Daily Graphic (undated). Clipping held at the British Film Institute.

'He and She, 'chutists, start new jobs', Evening Standard (undated). (Item 31: School for Danger/Now It Can Be Told file, held at British Film Institute.

Title unknown, Radio Times (21 March 1947).

'Bored Heroine', The Star (22 April 1948).

Franklin, O., 'Britain pays tribute to her war heroines: women secret agents at unveiling of memorial', Daily Graphic (8 May 1948).

'Heroines of the Second World War', London Illustrated News (undated) [May 1948].

Rodin, S., 'Mrs Smith: Train-wrecker, spy and Nazi-killer', date and newspaper unknown [1948]. Clipping held at FANY HQ. 


\section{Bibliography}

'British Films Take Honours: Five among six winners at Great Britain's box offices during year', Motion Picture Herald (6 January 1950).

Gleeson, J., 'Commando Girls: Beginning today: a story that will thrill you and make you proud', Daily Herald (24 April 1950).

Gleeson, J., 'Commando Girls: Part II: Peggy blows up a German convoy’, Daily Herald (25 April 1950).

Gleeson, J., 'Caught by the Gestapo: today's instalment of Commando Girls', Daily Herald (26 April 1950).

Gleeson, J., 'Torture - despair then rescue', Daily Herald (27 April 1950).

Gleeson, J., 'Commando Girls: Her bluff saved three men from death', Daily Herald (1 May 1950).

Gleeson, J., 'Commando Girls: the radio “widow”, Daily Herald (2 May 1950).

Gleeson, J., 'Commando Girls: the mother who died and the sisters', Daily Herald (3 May 1950).

Gleeson, J., title unknown, Daily Herald (5 May 1950).

Gleeson, J., 'Commando Girls: she led 3,500 guerillas', Daily Herald (6 May 1950).

Review of Odette, Daily Express (7 June 1950).

Baseden, Y., 'The tremendous things that happened to a quiet little English secretary: Secret Mission', Sunday Express (9 March 1952).

Baseden, Y., 'The tremendous things that happened to Yvonne Baseden: an English secretary meets the Gestapo', Sunday Express (16 March 1952).

Baseden, Y., 'An English Secretary in the torture cells of the Gestapo', Sunday Express (23 March 1952).

Gleeson, J., 'The secret heroines', Sunday Graphic (22 June 1952).

Churchill, P., title unknown, John Bull (10 October 1953).

Churchill, P., title unknown, John Bull (17 October 1953).

Billings, J., Kinematograph Weekly, n.26367 Vol. 25, No. 291 (1 April 1958).

'Painful Memories', Time (15 December 1958).

Author and title unknown, The Australian (25 April 1983).

Grice, E., 'Return of the White Mouse', Daily Telegraph (7 June 1994).

Obituary of Brian Stonehouse, The Times (10 December 1998).

'Weekend' magazine, The Guardian (16 September 2006).

\section{Posters, adverts, newsreels and films}

\subsection{Posters and adverts}

'Serve in the WAAF with the men who fly' (1941), artist Jonathon Foss.

'Just a good afternoon's work' (c.1942), artist unknown.

'On a man's job and equal to it', Weetabix, Picture Post, 6 June 1942.

\subsection{Newsreels}

All in a fighter's day's work (7 October 1940), Gaumont British.

Jane Brown changes her job (1942), Ministry of Information, Dir. H. Cooper.

Nightshift (1942), Dir. P. Roth. 


\title{
Bibliography
}

\subsection{Films}

The Gentle Sex (1943), Dir. L. Howard, starring J. Howard, R. John and J. Greenwood.

Millions Like Us (1943), Dirs. S. Gilliat and F. Launder, starring P. Roc and A. Crawford (Gainsborough Pictures).

School for Danger/Now It Can be Told (1944), Dir. T. Baird, starring H. Rée and J. Nearne (RAF Film Unit/Ministry of Information).

Odette (1950), Dir. H. Wilcox, starring A. Neagle, T. Howard and P. Ustinov.

Carve Her Name with Pride (1958), Dir. L. Gilbert, Prod. D. Angel, starring V. McKenna.

Gallipoli (1981), Dir. P. Weir, starring M. Gibson and M. Lee.

Plenty (1985), Dir. F. Schepisi, Prods. E. Pressman and J. Papp, starring M. Streep.

Charlotte Gray (2002), Dir. G. Armstrong, Prods. S. Curtis and D. Rae, starring C. Blanchett.

5.4 Film scripts held at the British Film Institute

School for Danger (also known as Now It Can Be Told), Box 10 Item 5, Thurold Dickinson Collection.

Odette - S8909 - 'Release script'. Also S3070 - 'Storyline' donated by Anna Neagle; S6244 - 'Screenplay', dated 26 June 1950, donated by Anna Neagle; S6245 'Screenplay', dated 5 December 1949, donated by Anna Neagle.

Carve Her Name with Pride, S13981 - Domestic version, post-production script.

\section{Radio and television}

\author{
6.1 Radio
}

Now It Can Be Told, broadcast 4 April 1950.

\subsection{Television series}

'Allo 'Allo!, BBC1, 1982-1992.

Dad's Army, BBC1, 1968-1977.

Secret Army, BBC2, 1977-9.

Wish Me Luck, ITV, 1987.

\subsection{Television documentaries}

The History of the Female Spy, The History Channel, 1984.

For Valour: Pearl Witherington, BBC1, 1995.

The Story of Nancy Wake, Codename The White Mouse, 1997, White Mouse Productions.

Timewatch: Secret Memories, BBC2, 1997.

Churchill's Secret Army, Channel 4, 2000.

Conflict, The History Channel, 2000.

Secret Agent, BBC2, 2000. 


\section{Bibliography}

Behind Enemy Lines: The Real Charlotte Grays, Channel 4, 2002.

Gladiators of World War Two, Channel 5, 2002.

Homeground: Secret Agent: The True Story of Violette Szabo, Channel 4, 2002.

\section{Internet Sources}

Forbes, A., 'The Princess who would be Spy', available online at: www.the-southasian.com/Sept2001/Noor\%20Inayat\%20Khan1.htm [Accessed 2002].

Harris, B., Lt Arthur Staggs, Wireless Operator: Hero of the French Resistance', available online at: http://users.tpg.com.au/berniezz/page3\%20Arthur.htm [Accessed 2006].

\section{Official Publications}

Foot, M. R. D., SOE in France: An Account of the Work of the British Special Operations Executive in France 1940-1944 (London: HMSO, 1966).

Hooks, J., British Policies and Methods of Employing Women in Wartime (Washington: US Government, 1944).

\section{Autobiographies}

Altbeker Cyprys, R., A Jump for Life: A Survivor's Journey from Nazi-Occupied Poland, ed. E. Potter (London: Constable, 1997).

Bleicher, H., Colonel Henri's Story (London: William Kimber, 1954).

Buckmaster, M., Specially Employed (London: Batchworth Press, 1952).

Buckmaster, M., They Fought Alone: The Story of British Agents in France (London: The Popular Book Club, 1959).

Burney, C., The Dungeon Democracy (London: William Heinemann Ltd, 1945).

Burney, C., Solitary Confinement (London: Clerke and Cockeran, 1952).

Churchill, P., Of Their Own Choice (London: Hodder and Stoughton, 1952).

Churchill, P., Duel of Wits (London: Hodder and Stoughton, 1953).

Churchill, P., The Spirit in the Cage (London: Hodder and Stoughton, 1954).

Cowburn, B., No Cloak, No Dagger (London: Jarrolds, 1960).

Delbo, C., None of Us Will Return (Boston: Beacon Press, 1968.)

Hahn Beer, E. and S. Dworkin, The Nazi Officer's Wife: How One Jewish Woman Survived the Holocaust (New York: Little, Brown and Company, 2000).

Heslop, R., Xavier: The Famous British Agent's Dramatic Account of His Work in the French Resistance (London: Rupert Hart-Davis, 1970).

Hudson, S., Undercover Operator: An SOE Agent's Experiences in France and the Far East (Barnsley: Leo Cooper, 2003).

Langelaan, G., Knights of Floating Silk (London: Hutchinson, 1959).

Millar, G., Maquis (London: William Heinemann Ltd, 1945).

Millar, G., Horned Pigeon (London: William Heinemann Ltd, 1946). 


\section{Bibliography}

Moszkiewiez, H., Inside the Gestapo: A Young Woman's Secret War (London: Warner Books, 1998).

Neagle, A., Anna Neagle Says: 'There's Always Tomorrow': An Autobiography (London: W.H. Allen, 1974)

Poirier, J., The Giraffe Has a Long Neck (London: Leo Cooper, 1995).

Rake, D., Rake's Progress (London: Leslie Frewin, 1968).

Rochester, D., Full Moon to France (London: Robert Hale Limited, 1978).

Sheppard, R., Missions Sécrètes et Déportation (Paris: Heinandal, 1999).

De Vomécourt, P., Who Lived to See the Day (London: Hutchinson, 1961).

Wake, N., The Autobiography of the Woman the Gestapo Called The White Mouse (Melbourne: Macmillan, 1985).

Walters, A-M., Moondrop to Gascony (London: Macmillan, 1947).

Zembsch-Schreve, G., Pierre Lalande: Special Agent. The Wartime Memoirs of Guido Zembsch-Schreve (London: Leo Cooper, 1996).

\section{Biographies}

Basu, S., Spy Princess: The Life of Noor Inayat Khan (Stroud: Sutton, 2006).

Braddon, R., Nancy Wake: The Story of a Very Brave Woman (London: The Book Club, 1956).

Cookridge, E., They Came From the Sky: The Stories of Lieutenant-Colonel Francis Cammaerts, DSO, Légion of Honour, Major Roger Landes, MC and Bar, Légion of Honour and Captain Harry Rée, DSO, OBE (London: Heinemann, 1965) (London: Corgi, 1976).

Fitzsimons, P. Nancy Wake: The Inspiring Story of One of the War's Greatest Heroines (London: Harper Collins, 2002).

King, S., Jacqueline: Pioneer Heroine of the Resistance (London: Arms and Armour Press, 1989). (On Yvonne Rudellat.)

Le Chêne, E., Watch for Me by Moonlight: A British Agent with the French Resistance (London: Eyre Methuen, 1973). (On Robert Boiteux-Burdett.)

Marshall, B., The White Rabbit: The Secret Agent the Gestapo Could Not Crack (London: Cassell and Co, 2000). (On Edward Yeo-Thomas.)

Masson, M., Christine: A Search for Christine Granville (London: Hamish Hamilton, 1975).

Minney, R., Carve Her Name with Pride: The Story of Violette Szabo (London: George Newnes, 1956).

Nicolson, D., Aristide: Warlord of the Resistance (London: Leo Cooper, 1994). (On Roger Landes.)

Ottoway, S., Violette Szabo: The Life That I Have: The Heroic Tale of a Female Spy in Nazi-Occupied France (Barnsley: Leo Cooper, 2002).

Overton Fuller, J., Madeleine: The Story of Noor Inayat Khan, George Cross, MBE, Croix de Guerre with Gold Star (London: Gollancz, 1951).

Overton Fuller, J., Born for Sacrifice: The Story of Noor Inayat Khan (London: Pan, 1957). 


\section{Bibliography}

Overton Fuller, J., Dericourt: The Chequered Spy (Wilton: Michael Russell, 1989). Seaman, M., Bravest of the Brave: The True Story of Wing Commander 'Tommy' Yeo-Thomas - SOE Secret Agent - Codename 'The White Rabbit' (London: Michael O’Mara, 1999). (On Edward Yeo-Thomas.)

Thomas, J., No Banners: The Story of Alfred and Henry Newton (London: WH Allen, 1955).

Tickell, J., Odette: The Story of a British Agent (London: Chapman and Hall, 1949). (On Odette Sansom.)

\section{Unpublished Theses}

Josephine Dolan, 'National Heroines: Representing Femininity and the Past in Popular Film and Literature, 1930-1955' (Ph.D. thesis, Lancaster University, 1997).

Julia Rosenzweig, 'The Construction of Policy for Women in the British Armed Forces: 1938-1948’ (M.Litt. dissertation, University of Oxford, 1993).

\section{General bibliography}

Adam, R., A Woman's Place, 1910-1975 (London: Chatto and Windus, 1975).

Anderson, B., Imagined Communities: Reflections on the Origin and Spread of Nationalism (London: Verso, 1983).

Baker, R., Drag: A History of Female Impersonation in the Performing Arts (London: Cassell, 1994).

Bakhtin, M., Problems of Dostoevsky's Poetics (Manchester: Manchester University Press, 1984).

Beecher Stowe, H., Uncle Tom's Cabin or Negro Life in the Slave States of America (London: C.H. Clarke, 1852).

Bell, L., Sabotage: The Story Of Lieutenant-Colonel J. Elder Wills (London: T. Werner Laurie Limited, 1957).

Berger, J., Ways of Seeing (London: BBC, 1975).

Binney, M., The Women Who Lived For Danger: The Women Agents of SOE in the Second World War (London: Hodder and Stoughton, 2002).

Binney, M., Secret War Heroes: Men of the Special Operations Executive (London: Hodder and Stoughton, 2005).

Bourdieu, P., 'The School as a Conservative Force: Scholastic and Cultural Inequalities', in Dale, R., Esland, G. and MacDonald, M., Schooling and Capitalism: A Sociological Reader (London: Routledge \& Kegan Paul, 1976).

Bourdieu, P., Outline of a Theory of Practice (Cambridge: Cambridge University Press, 1977).

Bourdieu, P., Sociology in Question (London: Sage, 1992).

Bourke, J., An Intimate History of Killing: Face-to-Face Killing in Twentieth-Century Warfare (London: Granta Publications, 1999). 


\section{Bibliography}

Braybon, G., Women Workers in the First World War: The British Experience (London: Croom Helm, 1981).

Braybon, G., and P. Summerfield, Out of the Cage: Women's Experiences in Two World Wars (London: Pandora, 1987).

Brownmiller, S., Femininity (London: Hamish Hamilton Ltd, 1984).

Butler, J., Bodies That Matter: On The Discursive Limits of Sex (London: Routledge, 1993).

Butler, J., Gender Trouble: Feminism and the Subversion of Identity (New York: Routledge, 1999).

Calder, A., The People's War (London: Cape, 1969).

A ChildLine Study, We Know it's Tough to Talk: Boys in Need of Help (London: ChildLine, 1996.)

Cohen, E., Human Behaviour in the Concentration Camp (London: Jonathon Cape Ltd, 1954).

Coleman, D., 'Population', in Halsey, A. (ed.) British Social Trends Since 1900: A Guide to the Changing Social Structure of Britain (Basingstoke: Macmillan Press, 1988).

Connell, B., Masculinities (Cambridge: Polity Press, 1995).

Connell, B., The Men and the Boys (Cambridge: Polity, 2000).

Craft, W., Running a Thousand Miles for Freedom: The Escape of William and Ellen Craft from Slavery (London: William Tweedie, 1860).

Dawson, G., Soldier Heroes: British Adventure, Empire and the Imagining of Masculinities (London: Routledge, 1994).

DeGroot, G., "Whose Finger on the Trigger?': Mixed Anti-Aircraft Batteries and the Female Combat Taboo', War in History, 4:4 (1997).

Deutsch, K., Nationalism and Social Communication: An Inquiry into the Foundations of Nationality (Cambridge, MA: The M.I.T Press, 1966).

Dudink, S., K. Hagermann and J. Tosh (eds), Masculinities in Politics and War: Gendering Modern History (Manchester: Manchester University Press, 2004).

Eitinger, L., 'Pathology of the Concentration Camp Syndrome', Archives of General Psychiatry, Vol. 5, October (1961).

Enloe, C., The Morning After: Sexual Politics at the End of the Cold War (London: University of California Press, 1993.)

Escott, B., Mission Improbable, A Salute to the RAF Women of SOE in Wartime France (Sparkford: Patrick Stephens Limited, 1991).

Foot, M. R. D., Resistance (London: Eyre Methuen, 1976).

Foot, M. R. D., Six Faces of Courage (London: Eyre Methuen, 1978).

Foot, M. R. D., SOE: An Outline History of the Special Operations Executive 1940-46 (London: BBC, 1984).

Fussell, P., The Great War and Modern Memory (Oxford: Oxford University Press, 1975).

Gilman, S., Seeing the Insane: A Cultural History of Madness and Art in the Western World (Wiley: New York, 1982). 


\section{Bibliography}

Ginsberg, E. (ed.), Passing and the Fictions of Identity (Durham: Duke University Press, 1996).

Gleeson, J., They Feared No Evil: The Stories of the Gallant and Courageous Women Agents of Britain's Secret Armies, 1939-45 (London: Hale, 1976).

Grinker R. and J. Spiegel, Men Under Stress (Philadelphia: Blakiston, 1945).

Grinker, R., 'The Psychosomatic Aspects of Anxiety', in Simon, A., Herbert, C. and Straus, R. (eds), The Physiology of Emotions (Illinois: Springfield, 1961).

Hall, G., Adolescence, 1:4 (1904).

Harrison, B., 'Oral History and Recent Political History', Oral History, 1: 3 (1972).

Heidegger, M., Being and Time (Oxford: Basil Blackwell, 1962).

Helweg-Larsen, P. et al., 'Famine Disease in German Concentration Camps: Complications and Sequels', Acta Psychiatrica Scandinavica, Supplementum, 83 (1952).

Higate, P., Military Masculinities: Identity and the State (London: Praeger, 2003).

Homden, C., The Plays of David Hare (Cambridge: Cambridge University Press, 1995).

Hunt, F., Gender and Policy in English Education: Schooling for Girls, 1902-44 (Hemel Hempstead: Harvester Wheatsheaf, 1991).

Jones, L., A Quiet Courage: Women Agents in the French Resistance (London: Corgi Books, 1990).

Kedward, R., In Search of the Maquis: Rural Resistance in Southern France, 1942-1944 (Oxford: Clarendon Press, 1993).

Kessler, R. et al., 'Lifetime and 12-month Prevalence of DSM-III-R Psychiatric Disorders in the United States: Results from the National Comorbidity Survey', Archives of General Psychiatry, 51 (1994).

Kramer, R., Flames in the Field: The Story of Four SOE Agents in Occupied France (London: Penguin Books, 1995).

Kremer, L., Women's Holocaust Writing: Memory and Imagination (Lincoln: University of Nebraska Press, 1999).

Lewis Herman, J., Trauma and Recovery: From Domestic Abuse to Political Terror (London: Pandora, 1998).

Light, A., Forever England: Femininity, Literature and Conservatism Between the Wars (London: Routledge, 1991).

Maclaren, R., Canadians Behind Enemy Lines, 1939-1945 (Vancouver: University of British Colombia Press, 1981).

Marwick, A., The Deluge: British Society and the First World War (London: Macmillan, 1965).

Marwick, A., Britain in the Century of Total War: War, Peace and Social Change, 1900-67 (Fakenham: Cox and Wyman Ltd, 1968).

Morrison, J., Ravensbrück: Everyday Life in a Women's Concentration Camp, 1939-45 (Princeton: Markus Wiener Publishers, 2000).

Mosse, G., The Image Of Man: The Creation of Modern Masculinity (Oxford: Oxford University Press, 1996). 


\section{Bibliography}

Myrdal, A., and V. Klein, Women's Two Roles: Home and Work (London: Routledge, 1956).

Newton, E., Mother Camp: Female Impersonators in America (Chicago: Chicago University Press, 1979).

Nicholas, E., Death Be Not Proud (London: Cresset Press, 1958).

Nicolson, M., What Did You Do In The War, Mummy? (London: Pimlico, 1996).

Overton Fuller, J., Double Agent? Light on the Secret Agents' War in France (London: Pan Books, 1961).

Page Baldwin, M., 'Subject to Empire: Married Women and the British Nationality and Status of Aliens Act', Journal of British Studies, 40: 4 (2001).

Paris, M., Over the Top: The Great War and Juvenile Literature in Britain (Westport: Praeger, 2004).

Pattinson, J., “The Best Disguise”: Performing Femininities for Clandestine Purposes During the Second World War, in Smith, A. (ed.) Gender and Warfare in the Twentieth Century: Textual Representations (Manchester University Press: Manchester, 2004).

Rich, A., 'Compulsory Heterosexuality and the Lesbian Continuum', Signs, 5:4 (1980), pp. 631-60.

Riley, D., Am I That Name?: Feminism and the Category of 'Women' in History (London: Macmillan, 1988).

Ringelheim, J., 'Women and the Holocaust: A Reconsideration of Research', Signs, 10 (1985).

Robins, L., and D. Regier, Psychiatric Disorders in America: The Epidemiologic Catchment Area Study (New York: Free Press, 1991).

Rose, S., Which People's War? National Identity and Citizenship in Britain, 1939-1945 (Oxford: Oxford University Press, 2003).

Russell, D., 'Rape and the Masculine Mystique', in Whitelegg, E. et al. (eds) The Changing Experience of Women (Oxford: Martin Robertson, 1982).

Sainsbury, J., The F Section Memorial (London: Hart Books, 1992).

Schwartz, P., 'Partisanes and Gender Politics in Vichy France', French Historical Studies, 16: 1 (1989), pp. 126-51.

Skeggs, B., Formations of Class and Gender: Becoming Respectable (London: Sage, 1997).

Slater, E., and J. Shields, 'Genetic Aspects of Anxiety', in Lader, M.(ed.), Studies of Anxiety (Ashford: Headley Brothers, 1967).

Smith, H., War and Social Change: British Society in the Second World War (Manchester: Manchester University Press, 1986).

Solzhenitsyn, A., The Gulag Archipelago, Volume 2: An Experiment in Literary Investigation, Pts. III-IV (London: Collins, 1976).

Stone, T., 'Creating a (Gendered?) Military Identity: The Women's Auxiliary Air Force in Great Britain in the Second World War', Women's History Review, 8:4 (1999).

Strongman, K., The Psychology of Emotion (Chichester: John Wiley and Sons, 1987). 


\section{Bibliography}

Summerfield, P., Women Workers in the Second World War: Production and Patriarchy in Conflict (London: Croom Helm, 1984).

Summerfield, P., Reconstructing Women's Wartime Lives: Discourses and Subjectivity in Oral Histories of the Second World War (Manchester: Manchester University Press, 1998).

Summerfield, P. and C. Peniston-Bird, 'The Home Guard in Britain in the Second World War: Uncertain Masculinities?', in Higate, P. (ed.), Military Masculinities: Identity and the State (London: Praeger Publishers, 2003).

Thomson, A., Anzac Memories: Living with the Legend (Oxford: Oxford University Press. 1994).

Turner, B., and T. Rennell, When Daddy Came Home: How Family Life Changed Forever in 1945 (London: Pimlico, 1995).

Vic-Dupont, X., L. Fichez and S. Weinstein cited in Eitinger, L. and A. Strøm, Mortality and Morbidity After Excessive Stress: A Follow-Up Investigation of Norwegian Concentration Camp Survivors (New York: Humanities Press, 1973).

Ward, I., F.A.N.Y. Invicta (London: Hutchinson, 1955).

Weitzman, L., 'Living on the Aryan Side in Poland: Gender, Passing and the Nature of Resistance', Ofer, D. and Weitzman, L. (eds) Women in the Holocaust (New Haven: Yale University Press, 1998).

Wheeler-Bennett, J., Nemesis of Power (London: Macmillan, 1954). 